\title{
Hubungan dukungan organisasi, kepuasan kerja, dan organizational citizenship behavior: pendekatan partial least square
}

\author{
Pingki Rizki Cahyani* \\ Manajemen, Fakultas Ekonomi Universitas Islam Attahiriyah, Jakarta, \\ Indonesia

\section{Hendryadi} \\ Sekolah Tinggi Ilmu Ekonomi Indonesia Jakarta, Indonesia
}

JMSAB

Paper type

Research paper
Keywords: POS, OCB, job satisfaction

\begin{abstract}
Abstrak
Penelitian ini bertujuan menguji hubungan persepsi dukungan organisasi (POS), kepuasan kerja dan organizational citizenship behavior (OCB) di salah satu unit layanan pemerintahan di Jakarta. Pendekatan survey dilakukan untuk memperoleh data melalui penyebaran kuesioner. Sebanyak 60 pegawai dijadikan sampel penelitian. Partial least square structural equation modeling (PLS-SEM) digunakan untuk menguji hipotesis. Hasil penelitian menunjukkan bahwa: terdapat hubungan positif POS dengan kepuasan kerja dan OCB, kepuasan kerja secara signifikan berkorelasi dengan OCB. Selain itu, kepuasan kerja terbukti sebagai variabel mediasi pada hubungan POS dengan OCB. Penelitian ini memberikan kontribusi pada upaya peningkatan OCB di sektor pemerintahan,
\end{abstract}

*Email korespondensi: pingkirizki96@gmail.com

Pedoman Sitasi: Cahyani, P.R \& Hendryadi (2018). Hubungan dukungan organisasi, kepuasan kerja, dan organizational citizenship behavior: pendekatan partial least square. Jurnal Manajemen Strategi dan Aplikasi Bisnis, 1(1), 47 - 58
Received: 24 September 2018

Accepted: 10 November 2018

Online: 31 December 2018

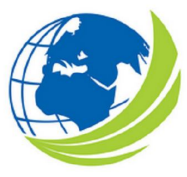
Jurnal Manajemen Strategi dan Aplikasi Bisnis, Vol 1, No.1, Desember 2018, pp. 47 - 58 eISSN 2655-237X 


\section{PENDAHULUAN}

Dalam lingkungan yang sangat kompetitif saat ini, organisasi terus mencari cara untuk memaksimalkan upaya kerja karyawan. Kompleksitas tugas dan meningkatnya penggunaan informasi teknologi menyebabkan adanya kekosongan dalam fungsi organisasi yang efektif (Gard dan Rastogi, 2006). Organisasi sekarang meyakini bahwa fungsi efektif dari suatu organisasi sangat tergantung ada upaya karyawan yang melampaui peran formal atau bekerja ekstra diluar tugas utama. Konsep ini dikenal dengan istilah istilah "Organizational Citizenship Behavior" atau OCB yang pertama kali diperkenalkan oleh Bateman dan Organ (1983). Konsep OCB kemudian menarik banyak minat peneliti dan akademisi di bidang perilaku organisasi. OCB dianggap dapat menjadikan organisasi lebih inovatif, fleksibel, produktif dan responsif untuk kelangsungan hidup dan kesuksesan perusahaan di masa depan (Organ, Podsakoff, \& MacKenzie, 2006) ; Podsakoff et al., 2000)

Organ (1990) mendefinisikan OCB sebagai perilaku dan tingkah laku yang menguntungkan secara organisasional yang tidak dapat di ukur berdasarkan kewajiban / peran formal atau ditimbulkan oleh ikatan kontrak atau imbalan tertentu. OCB telah dipelajari selama bertahun-tahun. Sejumlah penelitian telah berupaya mengidentifikasi anteseden OCB (Li, Chiaburu, \& Kirkman, 2017; Reader et al., 2016; Harris dan Kacmar, 2018; Miao et al., 2018; Arda et al., 2017; Joo dan Jo, 2017; Moo dan Shi, 2017) dan implikasi dari perilaku tersebut untuk fungsi organisasi yang efektif (seperti Dekas, Bauer, Welle, Kurkoski, \& Sullivan, 2013; Podsakoff, Blume, Whiting, \& Podsakoff, 2009; Podsakoff, Podsakoff, MacKenzie, Maynes, \& Spoelma, 2014). Studi yang kurang mendapatkan perhatian adalah memeriksa dampak negatif dari OCB, yang meliputi kinerja tugas dan kepuasan kerja yang lebih rendah, dan kehadiran politik organisasi (Bolino, Klotz, Turnley, \& Harvey, 2013).

Penelitian lebih baru seperti Somech dan Khotaba (2017) menempatkan iklim keadilan (keadilan distributif, prosedural, dan keadilan antar pribadi) dan psychological capital. Dalam penelitian ini, OCB ditempatkan sebagai mediator hubungan invasi dan iklim keadilan dan psychological capital. Chan dan Lai (2017) menguji hubungan kepuasan komunikasi dan persepsi keadilan dengan OCB. Penelitian lainnya lebih banyak yang menempatkan kepemimpinan sebagai anteseden OCB (Miao et al., 2018; Arda et al., 2017; Joo dan Jo, 2017; Moo dan Shi, 2017), dukungan organisasi yang dirasakan (Li, Chiaburu, \& Kirkman, 2017; Reader et al., 2016; Harris dan Kacmar, 2018), dan kepuasan kerja (Xie et al., 2017; Chan dan Lai, 2016).

Berdasarkan kajian sebelumnya, perceived organization support (POS) dan OCB masih memiliki kesenjangan besar yang memerlukan penelitian lebih lanjut. Pertama, banyak dari studi yang ada terutama berfokus pada konsekuensi langsung dari POS pada OCB dan perbedaan peran POS itu sendiri. Penelitian Li et al. (2017) menempatkan iklim dukungan organisasi sebagai moderator hubungan kepemimpinan yang berbedayakan dengan OCB, hubungan langsung POS dengan OCB (Reader et al., 2016; Harris dan Kacmar., 2018). Kedua, penelitian sebelumnya mengadopsi hubungan sederhana antara POS dan OCB. Di sisi lain, POS memiliki dampak positif pada kepuasan kerja (Kurtessis et al., 2017; Abou Hashish, 2017; Knapp et al., 2017) sehingga model hubungan antara POS, kepuasan kerja, dan OCB menarik untuk dieksplorasi lebih lanjut, khususnya di sektor pemerintahan.

Penelitian ini berusaha untuk membuat beberapa kontribusi. Pertama, objek penelitian yang diambil adalah unit layanan pemerintahan yang memiliki budaya birokrasi yang relatif kurang fleksibel dalam mengadaptasi perubahan. Dimasukkannya POS dan OCB dapat memberikan informasi mengenai model dukungan organisasi yang relevan, dan bagaimana dukungan tersebut dapat mempengaruhi OCB pegawai. Kedua, penelitian ini berfokus pada model hubungan POS, kepuasan kerja, dan OCB pada unit layanan pemerintahan, dan menempatkan kepuasan kerja 
sebagai pemediasi hubungan POS dengan OCB. Hasil penelitian ini dapat memperluas wawasan pengetahuan untuk riset berikutnya untuk memahami proses pembentukan OCB.

Untuk mencapai tujuan tersebut, artikel ini disusun sebagai berikut: pertama, dilakukan tinjauan literature teoretis tentang POS, kepuasan kerja karyawan, dan OCB. Kemudian, dilakukan analisis data empiris data yang dikumpulkan dari 60 pegawai di salah satu unit layanan pemerintah. Model persamaan struktural dengan pendekatan partial least square (PLS-SEM) digunakan untuk menguji hubungan kausal antara POS, kepuasan kerja karyawan kepuasan dan OCB. Artikel ini ditutup dengan kesimpulan, keterbatasannya dan saran penelitian selanjutnya.

\section{KAJIAN PUSTAKA}

Organizational citizenship behavior (OCB)

Organ (1988) merupakan peneliti pertama yang menggunakan istilah organizational citizenship behavior (OCB) dan mendefinisikannya sebagai perilaku individu yang bersifat diskresioner, tidak secara langsung atau eksplisit diakui oleh sistem penghargaan formal, dan secara agregat dapat meningkatkan fungsi efektif dari organisasi. Juga, kemauan karyawan untuk mengambil pekerjaan secara sukarela dari persyaratan formal sebagai komponen yang penting untuk menciptakan organisasi yang efektif (dalam Garg dan Rastogi, 2006). Konsep OCB dapat terdiri dari beberapa dimensi seperti: pertama, altruisme, yaitu mMembantu anggota lain dari organisasi dalam tugas mereka (misalnya secara sukarela membantu karyawan yang kurang terampil atau baru, dan membantu rekan kerja yang kelebihan beban atau tidak hadir dan berbagi strategi penjualan).

Kedua, courtesy (kesopanan), yaitu perilaku yang mencegah masalah yang berasal dari hubungan kerja (misalnya memberikan dorongan ada rekan kerja yang merasa kecewa dengan pengembangan profesional mereka). Ketiga, sportsmanship, yaitu menerima keadaan yang kurang ideal. Ke-empat, conscientiousness, yang mengacu pada pelaksanaan tugas sesuai dengan tanggung jawab (perilaku dalam peran); dan terakhir civic virtue, yaitu bertanggung jawab berpartisipasi dalam kehidupan perusahaan (mis. Menghadiri rapat / fungsi yang tidak diperlukan tetapi yang membantu perusahaan, mengikuti perubahan dalam organisasi, mengambil inisiatif untuk merekomendasikan bagaimana prosedur dapat ditingkatkan).

Hubungan POS dengan kepuasan kerja

Perceived organizational support (POS) dinyatakan sebagai kepercayaan karyawan pada organisasi mereka untuk menghargai kontribusi mereka dan peduli tentang kesejahteraan mereka (POS tinggi) cenderung bertindak dan berpikir dengan cara yang positif, sementara karyawan yang melihat organisasi mereka sebagai tidak peduli (POS rendah) cenderung berpikir dan berperilaku lebih negatif (Eisenberger et al., 2001). Dengan demikian, dalam pandangan literature banyak yang menghubungkan tingkat POS yang lebih tinggi untuk kepuasan kerja yang lebih tinggi dan keinginan berpindah yang lebih rendah (misalnya meta analisis yang dilakukan Kurtessis et al., 2017). POS meningkatkan rasa kesejahteraan karyawan dengan memenuhi kebutuhan relasional dan sosio-emosional untuk peningkatan diri. Akibatnya, karyawan yang memiliki POS yang tinggi sering dilaporkan memiliki tingkat kepuasan kerja yang lebih tinggi dan keinginan berpindah yang lebih rendah hanya karena mereka menerima manfaat pribadi yang diinginkan (Kurtessis et al., 2017, Abou Hashish., 2017; Knapp et al., 2017). Karena POS memenuhi kebutuhan sosio-emosional, penelitian ini mengajukan hipotesis sebagai berikut:

$\mathrm{H}_{1}$ : POS akan memiliki hubungan positif dengan kepuasan kerja. 


\section{Hubungan POS dengan OCB}

Hubungan antara POS dan dampaknya pada perilaku karyawan dijelaskan pada teori pertukaran sosial (Blau, 1964 dalam Shen et al., 2014). Berdasarkan teori ini, karyawan yang merasa didukung oleh organisasi memiliki kewajiban untuk menunjukkan perilaku kewargaan organisasional yang lebih (OCB) dan kinerja lebih baik karena perilaku tersebut bermanfaat bagi organisasi. Beberapa ahli seperti Eisenberg, Fasolo, \& Davis-LaMastro, (1990) berpendapat bahwa karyawan yang merasa bahwa mereka telah didukung dengan baik oleh organisasi mereka cenderung untuk membalas dengan melakukan lebih baik dan memiliki OCB yang lebih tinggi dibandingkan karyawan yang merasa tidak didukung. Banyak studi telah menunjukkan bahwa POS berhubungan positif dengan OCB. Dalam meta-analisis yang mewakili lebih dari 70 penelitian, misalnya, Rhoades dan Eisenberger (2002) menemukan POS memiliki hubungan signmifikan, dengan ukuran efek sedang dalam kaitannya dengan OCB. Dukungan empiris yang lebih baru di dilakukan oleh Reader et al., (2016) dan Harris dan Kacmar. (2018). Reader et al., (2016) menggunakan teori pertukaran sosial berhasil membuktikan hubungan langsung POS dengan OCB. Harris dan Kacmar. (2018) memberikan kesimpulan yang relative sama yaitu adanya hubungan antara POS dengan OCB, namun hubungan ini bersifat non-linier. Berdasarkan uraian tersebut maka dapat diajukan hipotesis:

\section{$\mathrm{H}_{2}$ : POS memiliki hubungan positif dengan OCB}

Hubungan kepuasan kerja dengan OCB

Kepuasan kerja karyawan didefinisikan sebagai keadaan emosi yang menyenangkan yang dihasilkan dari penilaian pekerjaannya (Locke, 1976, dalam Varela González \& García Garazo, 2006). Definisi ini sangat luas, karena termasuk karakteristik yang berkaitan dengan pekerjaan itu sendiri (misalnya upah, promosi, dan lainnya) dan lingkungan kerja. Beberapa penelitian menganggap kepuasan kerja karyawan sebagai variabel keseluruhan, sementara yang lain pertimbangkan dimensi-dimensinya yang berbeda, misalnya kepuasan dengan pekerjaan, supervisor, pembayaran, peluang untuk promosi, rekan kerja dan pelanggan - dan supervisi. Kepuasan kerja karyawan dianggap berhubungan positif dengan OCB. Dua teori mendukung hubungan ini: teori pertukaran sosial dan teori kontrak psikologis (dalam Varela González \& García Garazo, 2006). Berdasarkan perspektif dua teori tersebut, dasar hubungan terletak pada aturan timbal balik, atau karyawan yang puas akan membalas berperilaku positif seperti OCB (Xie et al., 2017; Chan dan Lai., 2016).

\section{$\mathrm{H}_{3}$ : Kepuasan kerja memiliki hubungan positif dengan OCB}

Kepuasan kerja memediasi hubungan POS dengan OCB

Didasarkan pada model teoritis yang sudah diuraikan sebelumnya bahwa POS dapat mempengaruhi kepuasan kerja karyawan (Kurtessis et al., 2017, Abou Hashish., 2017; Knapp et al., 2017), dan kepuasan kerja dapat mempengaruhi OCB (Varela González \& García Garazo, 2006; Xie et al., 2017; Chan dan Lai., 2016) maka model ini dapat bersifat mediasi sederhana, dimana karyawan yang memiliki tingkat POS tinggi cenderung memiliki kepuasan kerja yang tinggi, dan kepuasan yang tinggi tersebut selanjutnya berdampak pada OCB. Dengan demikian hipotesis yang diajukan adalah:

\section{$\mathrm{H}_{4}$ : Kepuasan kerja memediasi hubungan POS dengan OCB}


Jurnal Manajemen Strategi dan Aplikasi Bisnis, 1(1), 47-58

Cahyani, P.R \& Hendryadi. Hubungan dukungan organisasi...

\section{METODE PENELITIAN}

Desain penelitian

Penelitian ini menggunakan pendekatan kuantitatif. Suryani \& Hendryadi (2015:109) mendefinisikan penelitian kuantitatif merupakan penelitian yang menggunakan analisis data yang berbentuk numerik/angka. Pada dasarnya, pendekatan ini menggambarkan data melalui angka angka seperti presentasi tingkat pengangguran, kemiskinan, dara rasio keuangan, dan lain sebagainya. Tujuan penelitian kuantitatif yaitu mengembangkan dan mengunakan model matematis, teori dan/atau hipotesis yang berkaitan dengan fenomena yang diselidiki oleh peneliti. Berdasarkan tingkat ekplanasinya pendekatan yang digunakan adalah korelasional yaitu untuk menguji hubungan antar variabel yang di hipotesiskan. Berdasarkan waktu pengumpulan data penelitian ini menggunakan pendekatan cross-sectional yaitu data yang diambil dalam satu waktu.

Sampel penelitian

Sampel adalah sebagian dari populasi yang diambil dengan teknik atau metode tertentu untuk diteliti yang dianggap bisa mewakili populasi secara keseluruhan. Dengan kata lain pengertian sampel adalah sebagian, atau subset, dari suatu populasi (Suryani dan Hendryadi, 2015). Dalam penelitian ini peneliti mengambil sampel sebanyak 60 pegawai di 3 direktorat di salah satu Kementerian di Jakarta. Pengambilan sampel menggunakan pendekatan non-probability yaitu menggunakan teknik kuota yaitu masing-masing 20 orang perwakilan dari tiga direktorat.

Responden dalam penelitian ini terdiri dari 65\% laki-laki dan 35\% wanita. Berdasarkan masa kerja, lebih dari 75\% responden sudah bekerja lebih dari 6 tahun. Tingkat pendidikan responden adalah $60 \%$ berpendidikan Strata-1, dan $12 \%$ berpendidikan Strata- 2 . Sisanya berpendidikan $\mathrm{SMA} /$ sederajat.

Pengukuran

Pengukuran POS diadaptasi dari Survey of Perceived Organizational Support (SPOS) yang dikembangkan oleh Eisenberger et al. (2001). Sebanyak 7 (tujuh) digunakan untuk mengukur persepsi pegawai tentang apakah organisasi menghargai kontribusi mereka dan memperlakukan mereka dengan baik atau tidak baik dalam situasi yang berbeda. Tanggapan diukur pada skala Likert 5 poin mulai dari 5 =sangat setuju, hingga 1 = sangat tidak setuju .

Kepuasan kerja diadaptasi dari The Generic Job Satisfaction Scale yang dikembangkan oleh Macdonald dan (1997). Skala ini terdiri dari 10 (sepuluh) item yang diukur berdasarkan aspek-aspek pekerjaan seperti "saya berhubungan baik dengan supervisor" dan "saya merasa senang dengan pekerjaan ini". Tanggapan diukur pada skala Likert 5 poin mulai dari $5=$ sangat setuju, hingga $1=$ sangat tidak setuju.

Organizational citizenship behavior (OCB) diukur dengan mengadaptasi skala yang dikembangkan oleh Fox, Spector, Goh, Bruursema, \& Kessler, (2012). Skala awal terdiri dari 20 item, namun dalam ujicoba sebanyak 3 (tiga) item dieliminasi karena tidak memiliki kelayakan validitas item (loading factor < 0.50). Dengan demikian, skala akhir yang digunakan sebanyak 17 (tujuh belas) item yang diukur dengan skala Likert 5 poin mulai dari 5 =sangat setuju, hingga 1 = sangat tidak setuju.

Teknik Analisis

Teknik analisis data yang digunakan adalah Struktural Equation Modeling dengan pendekatan Partial Least Square (PLS-SEM). Metode yang digunakan adalah metode dua langkah yaitu melaporkan model pengukuran (outer model) dan model struktural (inner model) seperti yang disarankan dalam literatur (misalnya Chin, 2010; Hair et al., 2013). 


\section{HASIL DAN PEMBAHASAN}

Evaluasi outer model

Model pengukuran (outer model) adalah model pengukuran untuk menilai validitas dan reliabilitas model. Uji validitas dilakukan agar mengetahui kemampuan instrumen mengukur apa yang seharusnya diuji. Analisis data menggunakan software SmartPLS berdasarkan validitas konvergen (convergent validity), validitas diskriminan (discriminant validity), dan composite realiability.

Convergent validity dari model pengukuran dengan menggunakan indikator reflektif dinilai berdasarkan loading factor indikator-indikator yang mengukur construct tersebut. Rule of thumb yang biasanya digunakan untuk menilai validitas konvergen yaitu nilai loading factor harus lebih dari 0,7 untuk penelitian yang bersifat confirmatory dan nilai loading factor antara 0,6-0,7 untuk yang bersifat exploratory masih dapat diterima serta nilai AVE (Average Variance Extracted) harus lebih besar dari 0,5 (Hair et al., 2014). Berdasarkan hasil analisis dapat dinyatakan bahwa model pengukuran sudah memiliki validitas konvengen yang memadai dengan melihat koefisien bobot faktor yang seluruhnya lebih besar dari 0.50.

Tabel 1. Validitas konvergen

\begin{tabular}{|c|c|c|c|c|c|}
\hline $\begin{array}{l}\text { Konstrak / } \\
\text { Indikator }\end{array}$ & $\begin{array}{l}\text { Loading } \\
\text { factor. }\end{array}$ & std.dev & t-value & $\begin{array}{c}\text { Cronbach's } \\
\alpha\end{array}$ & $\mathrm{CR}$ \\
\hline OCB & & & & 0.92 & 0.93 \\
\hline OCB1 & 0.697 & 0.188 & 3.699 & & \\
\hline OCB2 & 0.677 & 0.192 & 3.527 & & \\
\hline OCB3 & 0.634 & 0.205 & 3.084 & & \\
\hline OCB5 & 0.659 & 0.097 & 6.796 & & \\
\hline OCB6 & 0.721 & 0.157 & 4.595 & & \\
\hline OCB7 & 0.724 & 0.108 & 6.724 & & \\
\hline OCB8 & 0.614 & 0.167 & 3.676 & & \\
\hline OCB9 & 0.526 & 0.099 & 5.315 & & \\
\hline OCB10 & 0.592 & 0.133 & 4.441 & & \\
\hline OCB11 & 0.646 & 0.106 & 6.105 & & \\
\hline OCB12 & 0.717 & 0.058 & 12.416 & & \\
\hline OCB13 & 0.843 & 0.051 & 16.651 & & \\
\hline OCB14 & 0.716 & 0.149 & 4.797 & & \\
\hline OCB15 & 0.610 & 0.087 & 7.037 & & \\
\hline OCB17 & 0.742 & 0.123 & 6.045 & & \\
\hline OCB18 & 0.506 & 0.159 & 3.172 & & \\
\hline OCB20 & 0.606 & 0.197 & 3.073 & & \\
\hline POS & & & & 0.958 & 0.965 \\
\hline POS1 & 0.833 & 0.053 & 15.692 & & \\
\hline POS2 & 0.925 & 0.026 & 35.749 & & \\
\hline POS3 & 0.850 & 0.040 & 21.457 & & \\
\hline POS4 & 0.920 & 0.026 & 35.803 & & \\
\hline POS5 & 0.907 & 0.045 & 20.238 & & \\
\hline POS6 & 0.915 & 0.036 & 25.113 & & \\
\hline POS7 & 0.907 & 0.041 & 22.091 & & \\
\hline
\end{tabular}


Jurnal Manajemen Strategi dan Aplikasi Bisnis, 1(1), 47-58

Cahyani, P.R \& Hendryadi. Hubungan dukungan organisasi...

Tabel 1. Lanjutan

\begin{tabular}{lrrrrr}
\hline SAT & & & & 0.852 & 0.884 \\
SAT1 & 0.552 & 0.124 & 4.439 & & \\
SAT2 & 0.507 & 0.133 & 3.796 & & \\
SAT3 & 0.580 & 0.143 & 4.069 & & \\
SAT4 & 0.797 & 0.084 & 9.532 & & \\
SAT5 & 0.503 & 0.082 & 6.104 & & \\
SAT6 & 0.820 & 0.07 & 11.697 & & \\
SAT7 & 0.758 & 0.084 & 9.058 & & \\
SAT8 & 0.774 & 0.048 & 15.957 & & \\
SAT9 & 0.680 & 0.117 & 5.831 & & \\
SAT10 & 0.554 & 0.135 & 4.099 & & \\
\hline Sur
\end{tabular}

Sumber: Sumber: diolah dengan SMARTPLS

Uji reliabilitas dalam SmartPLS 3.0 dapat menggunakan dua metode, yaitu cronbach alpha dan composite reliability. Menurut Hair et al (2014: 45) koefisien cronbach alpha dan composite reliability harus lebih besar dari 0,7 meskipun nilai 0,6 masih dapat diterima, dan nilai $\geq 0,8$ maka reliabilitas dinilai baik. Nilai Cronbach alpha berkisar antata 0.852 sampai dengan 0.958 pada tiga variabel laten, dan composite reliability berkisar antara 0.887 sampai dengan 0.965. Hasil ini mengindikasikan bahwa model pengukuran sudah memiliki reliabilitas komposit yang baik.

Evaluasi atas discriminant validy dinilai berdasarkan cross-loading pengukuran dengan construct-nya. Melalui hasil analisis di atas terlihat bahwa korelasi konstrak masing-masing variabel laten dengan indikatornya lebih besar dibandingkan dengan variabel laten lainnya. Seperti ditampilan tabel diatas, indikator Perilaku keanggotaan organisasi (OCB) memilliki korelasi yang lebih tinggi dengan laten lainnya seperti variabel dukungan organisasi (POS), kepuasan kerja (SAT). Hal yang sama juga terjadi pada indikator - indikator variabel lainnya sehingga dapat disimpulkan bahwa model sudah memenuhi validitas diskriminan.

Evaluasi model struktural (inner model)

Menurut Hair et al, (2014: 35), evaluasi model strutural dapat dilakukan melalui: evaluasi nilai R2, menilai koefisien jalur serta melaporkan hubungan yang signifikan dalam model struktural, dan prediksi relevansi prediktif model berdasarkan $\mathrm{Q}^{2}$.

Penilaian Varian Konstruktor Endogen ( $\mathrm{R}^{2}$ )

Nilai $\mathrm{R}^{2}$ disajikan dalam rentang angka 0-1, semakin nilai $\mathrm{R}^{2}$ mendekati angka 1 maka akan semakin baik. Berdasarkan hasil analisis diperoleh R-square $\left(\mathrm{R}^{2}\right)$ untuk SAT adalah sebesar 0.44 yang dapat diartikan kemampuan dukungan organisasi (POS) sebagai variabel eksogen mampu menjelaskan konstruk dari variabel endogen yaitu kepuasan kerja sebesar 44\%, dan sisanya dipengaruhi faktor lain. R-square $\left(\mathrm{R}^{2}\right)$ untuk POS adalah sebesar 0.554 yang berarti $55.4 \%$ OCB mampu dijelaskan oleh POS dan SAT.

Penilaian Prediksi (Predictive Relevance Q2)

Q2 diuji menggunakan prosedur blinfolding, yang merupakan fungsi sintesis dan lintas-validasi, dan model struktur dengan Q2 lebih besar dari nol yang dianggap memiliki prediktabilitas. Apabila nilai yang didapatkan 0,02 dianggap kecil, 0,15 dianggap sedang, dan 0,35 dianggap besar. Hasil perhitungan menunjukkan nilai Q2 predictive relevance sebesar 0,75 atau nilai prediksi relevan model adalah sebasar $75 \%$. Nilai predictive relevance sebesar $75 \%$ ini merupakan nilai prediksi dalam kategori tinggi/ besar (Hair et al., 2014: 129). 
Tabel 2. Nilai Koefisien $\mathrm{R}^{2}$ dan $\mathrm{Q}^{2}$

\begin{tabular}{lll}
\hline Konstrak Endogen & $\mathrm{R}^{2}$ & $\mathrm{Q}^{2}$ \\
\hline SAT & 0.440 & $\mathrm{Q}^{2}=1-(0,446)(0,56)$ \\
OCB & 0.554 & $\mathrm{Q}^{2}=0.75$ \\
\hline
\end{tabular}

Sumber: diolah

Pengujian Hipotesis

Pengujian hipotesis diuji dengan nilai probabilitasnya dan T-statistic nya. Untuk nilai probabilitas, nilai $\mathrm{P}$ value dengan alpha $5 \%$ atau kurang dari 0,05 . Nilai t-tabel untuk alpha 5\% adalah 1,96. Sehingga kriteria penerimaan hipotesa adalah ketika T-statistic $>$ t-tabel.

Tabel 3. Pengujian Hipotesis

\begin{tabular}{llccccl}
\hline Hipotesis & Model Hubungan & koefisien & std.dev & t-value & Values & Kesimpulan \\
\hline H1 & PS - SAT & 0.66 & 0.09 & 7.30 & 0.00 & Signifikan \\
H2 & PS -> OCB & 0.51 & 0.15 & 3.49 & 0.00 & Signifikan \\
H3 & SAT -> OCB & 0.73 & 0.18 & 4.08 & 0.00 & Signifikan \\
H4 & POS - > SAT ->OCB & 0.48 & 0.13 & 3.74 & 0.00 & Signifikan \\
\hline
\end{tabular}

Sumber: diolah

Hipotesis 1 dalam penelitian ini menyatakan bahwa dukungan organisasi (POS) memiliki pengaruh positif terhadap kepuasan kerja (SAT). Hasil perhitungan direct effect pada tabel 3 menunjukkan bahwa nilai original sample variabel dukungan organisasi (POS) sebesar 0,66 dan ini menandakan adanya pengaruh positif. Kemudian nilai T-statistic sebesar 7.302 nilai ini lebih besar dari t-tabel 1,96 dan nilai $\mathrm{P}$ value sebesar $0,000(<0.05)$. Dengan demikian dapat dinyatakan bahwa POS terbukti memiliki pengaruh positif dan signifikan terhadap kepuasan kerja (SAT). Hasil ini sejalan dengan temuan penelitian sebelumnya (seperti Kurtessis et al., 2017, Abou Hashish., 2017; Knapp et al., 2017).

Hipotesis 2 dalam penelitian ini menyatakan bahwa dukungan organisasi (POS) memiliki pengaruh positif terhadap OCB Hasil perhitungan direct effect menunjukkan bahwa nilai original sample sebesar 0,51, nilai T-statistic sebesar 3.489, dan p-value 0.00. Dapat dinyatakan bahwa POS terbukti berpengaruh secara postitif dan signifikan terhadap OCB. Hasil ini mendukung temuan Reader et al., (2016) dan Harris dan Kacmar. (2018) yang juga membuktikan hubungan langsung POS dengan OCB. Implikasi temuan ini adalah pimpinan dapat meningkatkan OCB pegawai melalui peningkatan POS pada dukungan penghargaan, kondisi pekerjaan, dukungan atasan dan keadilan.

Hipotesis 3 dalam penelitian ini menyatakan bahwa kepuasan kerja (SAT) memiliki pengaruh positif terhadap OCB. Hasil perhitungan direct effect menunjukkan bahwa nilai original sample sebesar 0,73, $t$ value $=4.084$ (lebih besar dari t-tabel 1,96), dan nilai $P$ value sebesar $0,000(<0.05)$. Dapat dinyatakan bahwa kepuasan kerja (SAT) berpengaruh secara postitif dan signifikan terhadap OCB. Temuan ini mendukung penelitian Xie et al. (2017) dan Chan dan Lai. (2016). Implikasi temuan ini adalah OCB pegawai dapat ditingkatkan melalui kepuasan kerja terutama pada kemampuan atasan dalam membuat kebijakan. Sedangkan untuk indikator terendah mengenai pertimbangan tentang pemberian asuransi kesehatan kepada karyawan perlu ditingkatkan.

Hipotesis 4 dalam penelitian ini menyatakan bahwa dukungan organisasi (POS) memiliki pengaruh positif terhadap OCB melalui Kepuasan kerja (SAT). Hasil perhitungan indirect effect pada menunjukkan bahwa nilai original sample sebesar 0,48, T-statistic sebesar 3.74 (>1.96), dan nilai P value sebesar $0,00(<0.05)$. Dapat dinyatakan bahwa dukungan organisasi (POS) secara tidak 
Jurnal Manajemen Strategi dan Aplikasi Bisnis, 1(1), 47-58

Cahyani, P.R \& Hendryadi. Hubungan dukungan organisasi...

langsung dapat mempengaruhi OCB melalui kepuasan kerja, atau kepuasan kerja terbukti mampu memediasi hubungan POS dengan OCB. Hasil penelitian ini membuktikan bahwa adanya hubungan tidak langsung antara dukungan organisasi terhadap perilaku keanggotaan organisasi melalui kepuasan kerja. Dengan demikian dapat disimpulkan bahwa hubungan antara dukungan organisasi terhadap perilaku keanggotaan organisasi dapat dilakukan secara langsung maupun tidak langsung.

\section{KESIMPULAN}

Kesimpulan

Penelitian ini memberikan kesimpulan bahwa POS merupakan faktor kunci dalam peningkatan OCB dan kepuasan kerja pegawai. Semakin tinggi persepsi dukungan organisasi dirasakan oleh pegawai maka semakin tinggi pula kepuasan dan OCB pegawai. Berikutnya, kepuasan kerja berpengaruh positif terhadap OCB karyawan, sehingga pegawai yang lebih puas akan lebih termotivasi untuk melakukan OCB tinggi dibandingkan pegawai yang memiliki tingkat kepuasan kerja lebih rendah. Terakhir, penelitian ini membuktikan peran kepuasan kerja pada hubungan POS dengan OCB. POS dalam bentuk dukungan penghargaan, kondisi pekerjaan, dukungan atasan dan keadilan dan karyawan dapat meningkatkan kepuasan kerja pegawai, dan pada akhirnya berdampak pada OCB.

Implikasi

Hasil penelitian ini memiliki dampak penting. Perusahaan-perusahaan yang menginginkan personel mereka memiliki OCB yang tinggi perlu mendorong dukungan organisasi dukungan penghargaan (pegawai perlu diyakinkan bahwa kontribusi mereka akan diharga dan organisasi memiliki perhatian kepada kesejahteraan mereka), perbaikan kondisi pekerjaan (seperti peralatan kerja dan teknologi yang digunakan sehingga dapat mendukung efektivitas kerja), dukungan atasan dalam bentuk perhatian akan karir dan kesediaan mendengarkan ide, pendapat dan keluhan, serta keadilan yaitu pegawai diperlakukan secara setara dalam hal promosi dan alokasi beban kerja. Semakin besar penekanan pimpinan pada tindakan ini, semakin tinggi tingkat kepuasan kerja, dan OCB yang ditunjukkan pegawai dalam kegiatan kerja sehari-hari.

Keterbatasan

Keterbatasan utama dari penelitian ini berasal dari tiga aspek: desain penelitian, sampel, dan kesederhanaan model. Data diambil dari survei dengan pendekatan cross-sectional di salah satu kementerian, sehingga kesimpulannya mungkin tidak secara umum berlaku, terutama di sektor bisnis. Sampel penelitian relative kecil meskipun secara umum sudah dapat diterima dalam penggunaan PLS-SEM. Model penelitian hanya menempatkan POS dan kepuasan kerja sebagai anteseden OCB, dan tidak mempertimbangkan karakteristik responden sebagai varibel kontrol. Atas dasar keterbatasan tersebut, maka riset mendatang perlu mengembangkan desain penelitian longitudinal dalam pengambilan data untuk membuktikan kausalitas hubungan yang lebih baik. Kedua, penelitian selanjutnya perlu memperbesar ukuran sampel dan memperluas objek riset ke sektor swasta. Ketiga, riset mendatang perlu mempertimbangkan faktor demografi dan kepribadian sebagai variabel kontrol dan variabel potensial lainnya seperti kinerja tugas sebagai dampak dari OCB.

\section{REFERENSI}

Abou Hashish, E. A. (2017). Relationship between ethical work climate and nurses' perception of organizational support, commitment, job satisfaction and turnover intent. Nursing ethics, 24(2), 151-166.

Arda, O. A., Delen, D., Tatoglu, E., \& Zaim, S. (2017). An analytic approach to assessing organizational citizenship behavior. Decision Support Systems, 103, 9-23. 
Bateman, T.S. and Organ, D.W. (1983), "Job satisfaction and the good soldier syndrome:the relationship between affect and employee citizenship", Academy of Management Journal, Vol. 26, pp. 587-95

Bolino, M. C., Klotz, A. C., Turnley, W. H., \& Harvey, J. (2013). Exploring the dark side of organizational citizenship behavior. Journal of Organizational Behavior, 34(4), 542-559.

Brown, L. A., \& Roloff, M. E. (2015). Organizational citizenship behavior, organizational communication, and burnout: The buffering role of perceived organizational support and psychological contracts. Communication Quarterly, 63(4), 384-404.

Chan, S. H. J., \& Lai, H. Y. I. (2017). Understanding the link between communication satisfaction, perceived justice and organizational citizenship behavior. Journal of business research, 70, 214223.

Chin, W. W. (2010). How to write up and report PLS analyses. In Handbook of partial least squares (pp. 655-690). Springer, Berlin, Heidelberg Csath, M. (2012), "Encouraging innovation in small and medium sized businesses: learning matters", Development and Learning in Organizations, Vol. 26 No. 5, pp. 9-13

Dekas, K. H., Bauer, T. N., Welle, B., Kurkoski, J., \& Sullivan, S. (2013). Organizational citizenship behavior, version 2.0: A review and qualitative investigation of OCBs for knowledge workers at Google and beyond. Academy of Management Perspectives, 27(3), 219-237.

Eisenberger, R., Armelli, S., Rexwinkel, B., Lynch, P. D., \& Rhoades, L. (2001). Reciprocation of perceived organizational support. Journal of Applied Psychology, 86, 42-51

Joo, B. K., \& Jo, S. J. (2017). The effects of perceived authentic leadership and core self-evaluations on organizational citizenship behavior: The role of psychological empowerment as a partial mediator. Leadership \& Organization Development Journal, 38(3), 463-481.

Garg, P., \& Rastogi, R. (2006). Climate profile and OCBs of teachers in public and private schools of India. International Journal of Educational Management, 20(7), 529-541.

Gupta, V., Agarwal, U. A., \& Khatri, N. (2016). The relationships between perceived organizational support, affective commitment, psychological contract breach, organizational citizenship behaviour and work engagement. Journal of advanced nursing, 72(11), 2806-2817.

Hair, J. F., Ringle, C. M., \& Sarstedt, M. (2011). PLS-SEM: Indeed a silver bullet. Journal of Marketing theory and Practice, 19(2), 139-152.

Hair, J.F, Sarstedt, M., Hopkins, L., \& G. Kuppelwieser, V. (2014). Partial least squares structural equation modeling (PLS-SEM) An emerging tool in business research. European Business Review, 26(2), 106-121.

Harris, K. J., \& Kacmar, K. M. (2018). Is more always better? An examination of the nonlinear effects of perceived organizational support on individual outcomes. The Journal of social psychology, 158(2), 187-200.

Henseler, J., Ringle, C. M., \& Sinkovics, R. R. (2009). The use of partial least squares path modeling in international marketing. In New challenges to international marketing (pp. 277-319). Emerald Group Publishing Limited.

Klotz, A. C., Bolino, M. C., Song, H., \& Stornelli, J. (2018). Examining the nature, causes, and consequences of profiles of organizational citizenship behavior. Journal of Organizational Behavior, 39(5), 629-647.

Knapp, J. R., Smith, B. R., \& Sprinkle, T. A. (2017). Is it the job or the support? Examining structural and relational predictors of job satisfaction and turnover intention for nonprofit employees. Nonprofit and Voluntary Sector Quarterly, 46(3), 652-671.

Kurtessis, J. N., Eisenberger, R., Ford, M. T., Buffardi, L. C., Stewart, K. A., \& Adis, C. S. (2017). Perceived organizational support: A meta-analytic evaluation of organizational support theory. Journal of Management, 43(6), 1854-1884. 
Jurnal Manajemen Strategi dan Aplikasi Bisnis, 1(1), 47-58

Cahyani, P.R \& Hendryadi. Hubungan dukungan organisasi...

Li, N., Chiaburu, D. S., \& Kirkman, B. L. (2017). Cross-level influences of empowering leadership on citizenship behavior: Organizational support climate as a double-edged sword. Journal of Management, 43(4), 1076-1102.

Macdonald, S., \& Maclntyre, P. (1997). The generic job satisfaction scale: Scale development and its correlates. Employee Assistance Quarterly, 13(2), 1-16.

Miao, C., Humphrey, R. H., \& Qian, S. (2018). A cross-cultural meta-analysis of how leader emotional intelligence influences subordinate task performance and organizational citizenship behavior. Journal of World Business, 53(4), 463-474.

Mo, S., \& Shi, J. (2017). Linking ethical leadership to employees' organizational citizenship behavior: Testing the multilevel mediation role of organizational concern. Journal of Business Ethics, 141(1), 151-162.

Organ, D. W. (1990). The motivational basis of organizational citizenship behavior. Research in organizational behavior, 12(1), 43-72.

Organ, D.W., Podsakoff, P.M. and MacKenzie, S.B. (2006), Organizational Citizenship Behavior: Its Nature, Antecedents, and Consequences, Sage, Thousand Oaks, CA

Osman, A., Othman, Y. H., Rana, S. S., Solaiman, M., \& Lal, B. (2015). The influence of job satisfaction, job motivation \& perceived organizational support towards organizational citizenship behavior (OCB): a perspective of American-based organization in Kulim, Malaysia. Asian Social Science, 11(21), 174.

Somech, A., \& Khotaba, S. (2017). An integrative model for understanding team organizational citizenship behavior: Its antecedents and consequences for educational teams. Journal of Educational Administration, 55(6), 671-685

Podsakoff, N. P., Whiting, S. W., Podsakoff, P. M., \& Blume, B. D. (2009). Individual-and organizationallevel consequences of organizational citizenship behaviors: A meta-analysis. Journal of applied Psychology, 94(1), 122.

Podsakoff, N. P., Podsakoff, P. M., MacKenzie, S. B., Maynes, T. D., \& Spoelma, T. M. (2014). Consequences of unit-level organizational citizenship behaviors: A review and recommendations for future research. Journal of Organizational Behavior, 35(S1), S87-S119.

Reader, T. W., Mearns, K., Lopes, C., \& Kuha, J. (2017). Organizational support for the workforce and employee safety citizenship behaviors: A social exchange relationship. Human Relations, 70(3), 362-385.

Shen, Y., Jackson, T., Ding, C., Yuan, D., Zhao, L., Dou, Y., \& Zhang, Q. (2014). Linking perceived organizational support with employee work outcomes in a Chinese context: Organizational identification as a mediator. European Management Journal, 32(3) , 406-412.

Suryani, dan Hendryadi. (2015). Metode Riset Kuantitatif: Teori dan Aplikasi pada Penelitian Bidang Manajemen dan Ekonomi Islam. Jakarta, Predanamedia Group

Varela González, J., \& García Garazo, T. (2006). Structural relationships between organizational service orientation, contact employee job satisfaction and citizenship behavior. International journal of service industry management, 17(1), 23-50.

Xie, B., Zhou, W., Huang, J. L., \& Xia, M. (2017). Using goal facilitation theory to explain the relationships between calling and organization-directed citizenship behavior and job satisfaction. Journal of Vocational Behavior, 100, 78-87. 
Jurnal Manajemen Strategi dan Aplikasi Bisnis, 1(1), 47- 58

Cahyani, P. R., \& Hendryadi. Hubungan dukungan organisasi...

\section{PROFIL PENULIS}

Pingki Rizki Cahyani lahir di Jakarta, pada 2 Juli 1996. Penulis menamatkan pendidikan strata 1 di Universitas Islam Attahiriyah program studi Manajemen konsentrasi SDM pada tahun 2018.

Hendryadi adalah dosen Prodi Manajemen Sekolah Tinggi Ilmu Ekonomi Indonesia Jakarta, Penulis memiliki ketertarikan pada penelitian bidang perilaku organisasi, pengembangan skala, dan perbankan syariah. Penulis dapat dihubungi di email: hendry.basrah@gmail.com. 